\title{
The Rational and Irrational Factors Underlying Property Buying Behavior
}

\author{
Njo Anastasia, Aileen Liana Suwitro \\ Petra Christian University, Surabaya, Indonesia \\ anas@peter.petra.ac.id
}

\begin{abstract}
Property buying behavior is part of the development of financial behavior. This research will be focused on the buyers perspectives on residential and commercial properties in Bali Island of Indonesia. Rational and irrational factors are the factors underlying the property buying process. The Physical, Location, Environment, Finance factors were part of the rational; while Psychological (over-confidence, conservatism bias, information and familiarity, herd behavior, mental accounting, and loss aversion), Emotion, Intuitional, Socialization, Evaluation were the irrational part. The purpose of this study was, first, to determine the factors that distinguish buyers behavior toward purchasing a property; second, to determine the factors that distinguish buyers behavior between buyers intending to live in compared to those seeking to invest. The study sample consisted of individuals who are prospective buyers and those who have bought property in Bali. Data were analyzed using Discriminant Analysis. The results showed that only financial factor that had significant impact on buyer decisions. Furthermore, this study also showed that there were significant differences in factors between buyers intending to live in compared to those seeking to invest. The factor were psychology, emotion, intuitional, and evaluation.
\end{abstract}

Keywords: Rational, irrational, live-in, investment, Bali

\section{Introduction}

Real estate is often approached as a financial asset. In reality, real estate is both a financial asset and a physical resource, a resource that is comprised of the site itself and the externalities that surround it and connect it to other parcels or activities. The price of this resource is a result of individual negotiations rather than some listing price that is offered to the broader market. Thus, the real estate discipline must be approached as a behavioral science because of its inefficient market. (DeLisle, 2001). Buying a property is one of the most significant financial decisions that people make, and it requires collecting a lot of information regarding its features. Behavioral research focuses on concepts that affect the market search and price-setting processes. Greater knowledge of the factors influencing buyers' behavior will lead to better understanding and prediction of decision making in real estate markets (Daly et al., 2003).

Survey of property behavior will be held in Bali because annual economic growth of Bali is very good at $6.6 \%$, above the national Indonesian economic growth by $6.1 \%$. A survey conducted by Knight Frank proved that land price in strategic areas of Bali has increased rapidly up to $43 \%$, the highest increase in the last 10 years. This land prices continue to rise earlier varies between 8\% to $16 \%$ ("Bali Property Prices Recording 2013", 2013). The Wealth Report 2014 issued by Knight Frank showed that the highest property prices in the world occurs in Jakarta that is equal to $33 \%$ and Bali was at thirdstage after Auckland, 22\% (Knight, 2014). Furthermore, this study is micro-oriented which investigates individual behaviors and the reasons behind them. The factors consisted of rational and irrational factors. This kind of studies has not much been investigated in the Indonesian market, particularly in the real estate. From previous studies, researcher classified the important factors affecting the decision to buy a property which are consist of Physical, Location, Environmental, Financial for the rational part; and Psychology, Emotion, Intuitional, Socialization, Evaluation for the irrational part.

\section{Statement of the problem:}

- What are the factors that distinguish buyer buyers behavior toward purchasing a property?

- What are the factors that distinguish buyers behavior between buyers intending tol ive in compared to those seeking to invest?

\section{Objective of the study:}

- To determine the factors that distinguish buyers behavior toward purchasing a property. 
- To determine the factors that distinguish buyers behavior between buyers intending to live in compared to those seeking to invest.

\section{Literature Review}

The researches about real estate buying behavior in Indonesia were not yet to be found in public literatures. This research uses a summary of existing variables identified in previous researches. Since the previous researches were conducted in countries that have significantly different conditions and cultures compared to Indonesia, particularly Bali Island, some adjustment were made. The increasing volume of real estate transaction in Bali over the past few years has been a phenomenon that increases the most of the investors' awareness of real estate. Therefore, this study will provide a better understanding of decision making context and influences to all real estate participants which are the investors, buyers, and agents. Traditional financial theory is based on idea or notion that investors act rationally and consider all information properly in decision-making process (Kishore, 2006). Salzman and Zwinkels (2013) agree that this theory deals with utility maximization concept (UM), which ended on Efficient Market Hypothesis (EMH). Consumer behavior theory comes from demand analysis in microeconomics to reducing the marginal utility and indifference curves. This study was able to explain how humans will be have in market if goods are in ideal conditions and able to explain importance of income and determining purchase price level. However, this study was notable to explain reasons behind their behavior and actions. Therefore, researchers add another factor to enhance this theory. Koklic and Vida (2009) focus on psychological factors and social decision. Katona (1953) adds psychology, sociology, and anthropology factors to a better understanding of consumer problem solving.

This study of buyers behaviour in the real estate purchase decision have provided the foundation of the factors affecting property buying decision, both rational and irrational. Ratchatakulpat et al. (2009) have provided an overall view of variables. The influences selected were physical, distance, locational, environmental, financial, legal, psychological, and evaluation. One problem study is that the irrational factors were not thoroughly discussed. A minority studies behavioural phenomena, with an eye for consumption function that pays attention to social and emotional side of homeownership (Salzman \& Zwinkels, 2013). Beracha \& Skiba (2014) have explained some of most common micro-level bias, such as overconfidence, mental accounting, loss aversion, familiarity bias, slow reaction to information. Salzman \& Zwinkels (2013) also provided a broader explanation of psychology and social determination of real estate decision making. The limitations bias the households' view on property are over-optimism, overconfidence, confirmation bias, momentum effect, herd behaviour, irrational exuberance, regret theory, money illusion, mental accounting, loss aversion, and home bias. Moreover, the study explained relationships of emotions and buyers decision making. Physical influences or property features is an important determinant of a household choice of residence (Quigley, 1976). Physical influences include design, property quality and property size has positive impacts on buyers' decision to purchase a property (Adair et al., 1996; Daly et al., 2003; Ratchatakulpat et al., 2009). Lindberg, Gärling, \& Montgomery (1989); Louviere and Timmermans (1990) found that another important influences is property location, it was included in the most of previous researches (Adair et al., 1996; Si, 2012; Haddad et al., 2011). Furthermore, Wang \& Li (2004) found that environmental influences were more important than property itself. Gabriel \& Rosenthal (1989) stated that households individual characteristics neighborhood quality was concluded as one of the determinants of a household's residential choice.

\section{Methodology}

A survey was both hand-delivered and sent online amongst prospective real estate buyers and those who already bought at least one property such as house, villa and condominium-hotel (condotel) in Bali, Indonesia, specifically property in Badung and Denpasar Region. The questionnaires were given to 100 respondents. They consisted of three main sections: background information of respondents, the rational factors and the irrational factors from the literature that are created for this research (see Appendix 1). Questions used a five-point Likert scale from $1=$ 'highly unimportant' or 'strongly disagree' to 5 = 'highly important' or 'strongly agree'. The research population consisted of both potential real estate buyers and those who already bought a property in Bali from anywhere in the world. Recruiting respondents was purely on the basis of convenience and gathered from Bali community including expats. The purpose was to obtain a large number of completed questionnaires quickly and efficiently. The survey was completed in 2 weeks. Discriminant Analysis using SPSS program was used in analyzing the data to test the hypotheses. Discriminant analysis is used to analyze relationships between a non-metric dependent 
variable and metric or dichotomous independent variables. Discriminant analysis attempts to use the independent variables to distinguish among the groups or categories of the dependent variable.

\section{Results and Discussion}

The first stage of survey analysis describes respondent demographic. The property purchasers are shown in table 1. There are 57 respondents who have not bought property in Bali and 43 respondents who have bought at least one property in Bali. 31 respondents in the group that have not bought property in Bali are intending to live in, while 26 respondents intending to invest. As many as 27 respondents have bought a property in Bali for live in, while 16 have bought one for investment. The largest group of age is 25-35 years and the largest group that has bought property in Bali is 46-55 years. Most of the respondents are married with children (60\%). The majority are from Bali (40 respondents), and among 33 nonIndonesians, 15 of them are from Australia.

Table 1: Respondent Demographic Characteristics

\begin{tabular}{|c|c|c|c|c|}
\hline \multirow{2}{*}{ Respondent Characteristics } & \multicolumn{2}{|c|}{ Have not bought } & \multicolumn{2}{|c|}{ Have bought } \\
\hline & Live In & Investment & Live In & Investment \\
\hline \multicolumn{5}{|l|}{ Gender : } \\
\hline Male & 17 & 17 & 20 & 11 \\
\hline Female & 14 & 9 & 7 & 5 \\
\hline \multicolumn{5}{|l|}{ Age group : } \\
\hline Under 25 years & 4 & 5 & 0 & 0 \\
\hline $25-35$ years & 11 & 11 & 4 & 4 \\
\hline $36-45$ years & 8 & 6 & 8 & 3 \\
\hline $46-55$ years & 6 & 3 & 8 & 5 \\
\hline Over 56 years & 2 & 1 & 7 & 4 \\
\hline \multicolumn{5}{|l|}{ Marital Status: } \\
\hline Single & 10 & 11 & 2 & 2 \\
\hline Married without children & 5 & 2 & 6 & 2 \\
\hline Married with children & 16 & 13 & 19 & 12 \\
\hline \multicolumn{5}{|l|}{ Nationalities: } \\
\hline Indonesian & 22 & 21 & 12 & 12 \\
\hline Not Indonesian & 9 & 5 & 15 & 4 \\
\hline \multicolumn{5}{|l|}{ Origin Continent: } \\
\hline United States & 2 & 1 & 4 & 0 \\
\hline Europe & 3 & 2 & 7 & 0 \\
\hline Australia & 4 & 2 & 5 & 4 \\
\hline Asia (Indonesia) & 22 & 21 & 11 & 12 \\
\hline \multicolumn{5}{|l|}{ Origin City/ Province: } \\
\hline Bali & 18 & 7 & 11 & 4 \\
\hline Surabaya & 1 & 8 & 1 & 7 \\
\hline Jakarta & 0 & 2 & 2 & 1 \\
\hline Others & 12 & 9 & 13 & 4 \\
\hline
\end{tabular}

Table 2: Respondents Purchasing Characteristics

\begin{tabular}{lcccc}
\hline \multicolumn{1}{c}{ Characteristic } & \multicolumn{2}{c}{ Have not bought } & \multicolumn{2}{c}{ Have bought } \\
\cline { 2 - 5 } & Live In & Investment & Live In & Investment \\
\hline Living Status: & 9 & & & \\
$\quad$ Parents/relatives home & 14 & 5 & 0 & 4 \\
Rent & 8 & 10 & 4 & 1 \\
Own house & 21 & 17 & 23 & 11 \\
Number of Property Bought & anywhere): & 5 & 0 & 0 \\
$\quad$ None & 1 & 1 & 13 & 5 \\
1 & 0 & 3 & 1 & 3 \\
2 & 9 & 13 & 8 \\
$3+$ & 20 & 13 & 13 & \\
Type of Property: & 10 & 10 & 14 & 4 \\
$\quad$ House & 1 & 3 & 0 & 7 \\
$\quad$ Villa & & & & \\
$\quad$ Condotel/Apartment & & & & \\
\hline
\end{tabular}


Table 2 provides the details of respondent purchase characteristics, 57 respondents have not bought property and consist of 31 respondents choose to live in compare to 26 respondents choose to investment in property. The others 43 respondents already have bought property. Furthermore, more than half of respondents already have their own house (34 respondents). The largest group has not bought a property anywhere (38 respondents) and the majority of respondents have considered purchasing a house (51 respondents) rather than a villa (38 respondents) and a condotel/ apartment (11 respondents).

Before analyzing rational and irrational factor using discriminant analysis, the data were tested for the validity, reliability, and normality.

Validity and reliability analysis: The validity analysis was conducted to see if the questions given were valid. It was conducted by calculating the r-value (corrected item-total correlation). The r-value for 47 items were positive and well exceeded r-table (0.195), hence, the validity was established. The reliability analysis following the validity analysis was conducted by calculating the Cronbach's alpha for each factor. Cronbach's alpha for the eight constructs well exceeded 0.195 , hence, established their reliability.

Table 3A: Validity and Reliability Rational Factors

\begin{tabular}{|c|c|c|c|}
\hline Factors & Variables & Cronbach's Alpha & Corrected Item-Total Correlation \\
\hline \multirow{8}{*}{ Physical } & P1 & \multirow{8}{*}{0,856} & 0,649 \\
\hline & $\mathrm{P} 2$ & & 0,630 \\
\hline & P3 & & 0,508 \\
\hline & $\mathrm{P} 4$ & & 0,525 \\
\hline & P5 & & 0,700 \\
\hline & P6 & & 0,659 \\
\hline & P7 & & 0,571 \\
\hline & P8 & & 0,575 \\
\hline \multirow{9}{*}{ Location } & L1 & \multirow{9}{*}{0,806} & 0,592 \\
\hline & $\mathrm{L} 2$ & & 0,459 \\
\hline & L3 & & 0,546 \\
\hline & $\mathrm{L} 4$ & & 0,694 \\
\hline & L5 & & 0,690 \\
\hline & L6 & & 0,329 \\
\hline & L7 & & 0,608 \\
\hline & L8 & & 0,517 \\
\hline & L9 & & 0,234 \\
\hline \multirow{7}{*}{ Environmental } & E1 & \multirow{7}{*}{0,804} & 0,531 \\
\hline & E2 & & 0,610 \\
\hline & E3 & & 0,549 \\
\hline & E4 & & 0,587 \\
\hline & E5 & & 0,490 \\
\hline & E6 & & 0,658 \\
\hline & E7 & & 0,417 \\
\hline \multirow{6}{*}{ Financial } & F1 & \multirow{6}{*}{0,920} & 0,491 \\
\hline & $\mathrm{F} 2$ & & 0,893 \\
\hline & F3 & & 0,920 \\
\hline & $\mathrm{F} 4$ & & 0,933 \\
\hline & F5 & & 0,927 \\
\hline & F6 & & 0,478 \\
\hline
\end{tabular}

The results of Corrected item-total correlation and Cronbach's alpha were reported in Table 3A for rational factors and table 3B for irational factors. 
Table 3B: Validity and Reliability Irrational Factors

\begin{tabular}{lccc}
\hline \multicolumn{1}{c}{ Factors } & Variables & Cronbach's Alpha & Corrected Item- Total Correlation \\
\hline \multirow{5}{*}{ Psychology } & PS1 & & 0,400 \\
& PS2 & & 0,286 \\
& PS3 & 0,646 & 0,330 \\
& PS4 & & 0,339 \\
& PS5 & & 0,374 \\
Emotion & PS6 & & 0,550 \\
& EM1 & & 0,244 \\
& EM2 & \multirow{2}{*}{0,578} & 0,530 \\
Intuitional & EM3 & & 0,277 \\
& EM4 & & 0,436 \\
\hline \multirow{3}{*}{ Socialization } & I1 & & 0,298 \\
& I2 & 0,528 & 0,333 \\
& I3 & & 0,404 \\
\hline \multirow{3}{*}{ Evaluation } & S1 & & 0,518 \\
& S2 & \multirow{2}{*}{0,713} & 0,609 \\
& S3 & & 0,564 \\
& S4 & & 0,318 \\
\hline
\end{tabular}

The ratio of skewness $=0.008 / 0.241=0.0332$; and the ratio of kurtosis $=0.197 / 0.478=0.412$. Because of the ratio of skewness and kurtosis are between -2 to +2 , it can be concluded that the data are normally distributed.

Table 4: Normality test

\begin{tabular}{lcccc}
\hline & \multicolumn{2}{c}{ Skewness } & \multicolumn{2}{c}{ Kurtosis } \\
\cline { 2 - 5 } & Statistic & Std. Error & Statistic & Std. Error \\
\hline $\begin{array}{l}\text { Unstandardized } \\
\text { Residual }\end{array}$ & 0,008 & 0,241 & 0,197 & 0,478 \\
\hline
\end{tabular}

Analysis will be continued by discriminant analysis to determine differences in rational and irrational factors that influence consumers in making decision to buy a property in Bali. Subsequently also to know their purpose which is to buy for live in or investmenta property for the future.

Table 5: Box's M

\begin{tabular}{lcc}
\hline & $\begin{array}{c}\text { 'Have not bought' and } \\
\text { 'Have bought' }\end{array}$ & $\begin{array}{c}\text { 'Live In' and } \\
\text { 'Investment' }\end{array}$ \\
\hline F & 14,108 & 0,792 \\
Sig. & 0,000 & 0,637 \\
\hline
\end{tabular}

Box's $\mathrm{M}$ test results for group to buy and have bought yet demonstrated that F-value is 14.108 , it is significant at 0.000 and the probability is below 0.05 , it can be concluded that covariance matrix between groups is different and in this case violates discriminant assumption. However, a discriminant function analysis remains robust despite the assumption of homogeneity of variance was not met with data requirements and did not have outliers (Ghazali, 2008). Box's M test results for the group to live in and investments how that F-value is 0.792 and it is significant at $0.637>0.05$, which means that data between groups live in and investment have a covariance matrix equation.

Table 6 shows that all variables except financial have Wilk's Lambda values above 0.9. Getting closer to 1 , the data tend to be equal for each group. The significant value (F-test), there are four significant variables that have value $<0.05$, which shows the difference between group' Have not bought' and 'Have bought', ie financial, psychology, socialization, and evaluation. However, these results still need to be processed to ensure validity. 
Table 6: Test of Equality of Group Means - Have not bought and have bought

\begin{tabular}{lcc}
\hline Factors & Wilk's Lambda & Sig. \\
\hline Physical & 0,966 & 0,065 \\
Location & 0,966 & 0,068 \\
Environmental & 0,978 & 0,144 \\
Financial & 0,809 & 0,000 \\
Psychology & 0,931 & 0,008 \\
Emotion & 0,970 & 0,084 \\
Intuitional & 0,992 & 0,369 \\
Socialization & 0,943 & 0,017 \\
Evaluation & 0,946 & 0,020 \\
\hline
\end{tabular}

Table 7: Variables entered in discriminant

\begin{tabular}{lcccccc}
\hline \multicolumn{1}{c}{ Step } & Entered & Statistic & Sig. & Wilk's Lambda & Chi-Square & Sig. \\
\hline 1 & Financial & 23.191 & $5.341 \mathrm{E}-006$ & 0,809 & 20,709 & 0,000 \\
Original & $67 \%$ & & & & \\
\multicolumn{2}{l}{ Cross-validated } & $67 \%$ & & & & \\
\hline
\end{tabular}

Inclusion of variables using stepwise process (stages), starting with variable which has F-test (statistics) the highest one. It can be seen, only one variable, financial. Thus, purchase consideration of respondents who have not bought property and have bought property influenced by financial factor only. The Wilks' Lambda indicates a significant difference between two groups on discriminant model. So respondent behavior between the two groups is significantly different (significant $0.000<0.05$ ). The results of classification on original and leave-one-out-cross validation methods, both produce a figure $67 \%$, which is the accuracy rate is high. That is various table interpretations that are valid for use.

Table 8: Mean - Have not bought and have bought

\begin{tabular}{llcc}
\hline Factors & Indicators & Have not bought & Have bought \\
\hline Financial & F1 (Price) & 4,67 & 4,23 \\
& F2 (Interest rate) & 4,35 & 3,42 \\
& F3 (Mortgage) & 4,21 & 3,26 \\
& F4 (Monthly payment) & 4,28 & 3,28 \\
& F5 (Term of payment) & 4,32 & 3,19 \\
& F6 (Length of period property & 3,91 & 3,21 \\
& was on the market) & & \\
\hline
\end{tabular}

From the table 8, it can be seen that all financial factors indicators factors in have not bought group has a mean value higher than have bought group. This means that respondents who have bought property in Bali more attention to property prices, interest rates, mortgage amount, maximum amount of monthly installments, payment terms, and length of the property market.

Table 9: Test of Equality of Group Means - Live In and Investment

\begin{tabular}{lcc}
\hline Factors & Wilk's Lambda & Sig. \\
\hline Physical & 1,000 & 0,833 \\
Location & 0,991 & 0,346 \\
Environmental & 0,988 & 0,278 \\
Financial & 0,983 & 0,200 \\
Psychology & 0,956 & 0,037 \\
Emotion & 0,925 & 0,006 \\
Intuitional & 0,928 & 0,007 \\
Socialization & 0,982 & 0,188 \\
Evaluation & 0,950 & 0,025 \\
\hline
\end{tabular}

Table 9 shows that all variables except psychology, emotion, intuitional, and evaluation have significant value (F-test) $<0.05$. The three variables showed the difference between group'Live in' and 'Investment'. However, these results still need to be processed to ensure validity. The significant value (F-test) in table 10 showed there are three significant variables value $<0.05$, ie emotion, psychology, and intuitional. This 
means that the difference between purchase consideration properties respondents intended to live in and respondent intended to investment lies in factors psychology, emotion, intuitional, and evaluation.

Table 10: Variables entered in discriminant

\begin{tabular}{lcccccc}
\hline \multicolumn{1}{c}{ Step } & Entered & Statistic & Sig. & Wilk's Lambda & Chi-Square & Sig. \\
\hline 1 & Emotion & 7,991 & 0,006 & 0,727 & 30,649 & 0,000 \\
2 & Psychology & 9,461 & 0,000 & & & \\
3 & Intuitional & 9,664 & $1.235 \mathrm{E}-005$ & & & \\
4 & Evaluation & 8,932 & $3.628 \mathrm{E}-006$ & & & \\
\multicolumn{2}{l}{ Original } & $73 \%$ & & & & \\
\multicolumn{2}{l}{ Cross-validated } & $68 \%$ & & & & \\
\hline
\end{tabular}

Stepwise process was conducted to select the variables that are significantly affect the live in and investment buyers behavior. The variables selected are emotion, psychology, intuitional, and evaluation (Table 10). The Wilk's Lambda indicates that there is a significant difference between two groups (live in and investment) in discriminant model. The original classification result is $73 \%$. With the leave-one-out cross validation method conducted, the classification result becomes $68 \%$. The results are still high and therefore the discriminant models are valid.

From Table 11, it can be concluded that in terms of psychology, those who aim to invest have four biases (deviation) which tend to be greater. Such irregularities are over-confidence, herd, mental accounting, and loss aversion. While group live in does not pay attention more to the latest economic news and prefer properties in areas that are closer or familiar. Ratchatakulpat et al (2009) research on prospective buyers in Australia also found that those seeking to invest are more concern about the psychology factor. From the emotional side, the investment group pays more attention to security than live in groups. However, the live in group prefers to live in the properties that reflect their personal characteristics. In addition, this group also prioritize comfort and better appreciate owned property. Focus to intuition of respondents, the group who aims to live in has more intuition and confidence than the group that buys property for investment.Where respondents who aim to invest are more confident in terms of generating large returns. Investment buyers consider all the evaluation factors are more important than buyers who intend to live in. Investment buyers are more concerned with inspecting fewer than 10 properties and the purchasing process taking under 2 months. They also prefer real estate agents who explain the forms and legalities of the process. These findings regarding the evaluation factors are the same as the study by Ratchatakulpat et al (2009).

Table 11: Mean - Live In and Investment

\begin{tabular}{clcc}
\hline Factors & \multicolumn{1}{c}{ Indicator } & Live In & Investment \\
\hline \multirow{5}{*}{ Psychology } & 3,43 & 3,93 \\
& PS1(over-confidence) & 3,12 & 2,90 \\
& PS2(conservatism bias) & 3,95 & 3,93 \\
& PS3(familiarity bias) & 3,21 & 3,48 \\
& PS4(herd behavior) & 3,36 & 3,79 \\
& PS5(mental accounting) & 3,36 & 3,76 \\
& PS6(loss aversion) & 3,67 & 3,93 \\
& EM1(safety) & 3,62 & 3,40 \\
Emotion & EM2(self-image) & 4,60 & 4,14 \\
& EM3(comfortable) & 4,28 & 3,93 \\
& EM4(meaning) & 4,05 & 3,64 \\
\multirow{5}{*}{ Evaluational } & 3,88 & 3,62 \\
& I1(first impression) & 3,76 & 3,93 \\
& I2(self-opinion) & 3,33 & 3,71 \\
& I3(assurance) & 4,24 & 4,45 \\
& EV1 (less than 10 property) & 3,26 & 3,45 \\
& EV2 (legality) & &
\end{tabular}




\section{Conclusion}

This study concluded that there was a significant difference in decision making regarding buying property in Bali between respondents who have not bought property in Bali and those who have. The factor was financial, where those who have not bought property in Bali were more concern about the financial factor. The study also found that there were significant differences in decision making regarding buying property in Bali between respondents intending to live in compared to those seeking to invest. The factors were psychology, emotion, intuitional, and evaluation. Investment buyers considered psychology, intuitional, and evaluation factors more important in their decision making processes.

Recommendations: This section will discuss some limitations that this study has. First, the sample of this study is only 100 respondents and since the respondents were picked randomly, the respondents who were interested in purchasing and have not purchased any properties in Bali were assumed that they are the prospective purchasers of property. However, individuals who are interested in purchasing property vary in their intentions regarding the likelihood and timing of actually purchasing a property. Some of them may or may not view numbers of properties with intention to purchase whether in immediate time or a really long period of time. Prospective buyers may also do not have a clear cut decision to live in or invest. And therefore, the outcomes may not represent the buyers' behavior perfectly. Secondly, the one-shot survey only captures a certain point in time. Given the nature of buyer behavior, it will be great if the process of buyers' decision making is discussed and therefore add more quality to the output. One of the most important implications of this study is the distinctions between live in and investment for the prospective buyers. Most of the prospective buyers may not have a clear intention of purchasing a property for live in or investment. There are several stages found in the process of searching a property. The prospective buyers at earlier stages (those who have not yet started searching) of the process may not have the same level of understanding the importance of each factors with those who are already at further stage of the process (those who have already viewed several options).

To ascertain more degree of generalization for the study, further research could be conducted to include respondents from the real estate offices, in addition to the buyers and prospective buyers of properties. This way, we may get respondents with bigger possibilities of actually searching for properties and considering to purchase. Moreover, it was strongly recommended for further research to differentiate the factors according to the types of property. The differentiated factors may provide more specific characteristic of each type of property, and therefore the outputs will better explain the buyers' behavior towards each type of property. Another avenue for future research is to add more factors or variables to the study, such as marketing, legal, culture and other factors represent real estate financial behavior.

\section{References}

Adair, A., Berry, J. \& McGreal, S. (1996). Valuation of Residential Property: Analysis of Participant Behavior. Journal of Property Valuation \& Investment, 14(1), 20-35.

Beracha, E. \& Skiba, H. (2014). Real Estate Investment Decision-Making in Behavioral Finance in H. K. Bakers \& V. Ricciardi. (Eds.) Investor Behavior: The Psychology of Financial Planning \& Investing, John Wiley \& Sons, Inc. New Jersey.

Daly, J., Gronow, S., Jenkins, D. \& Plimmer, F. (2003). Consumer behavior in the valuation of residential property: A comparative study in the UK, Ireland and Australia. Journal of Property Management, 21(5), 295-314.

DeLisle, J. R. (2001). Behavioral Theory and Residential Appraisal. The Appraisal Journal, 3, 493-506

Gabriel, S. \& Rosenthal, S. (1989). Housing location and race: Estimates of a multinomial logit model. The Review of Economics and Statistics, 71(2), 240-249.

Ghazali, I. (2008). Application of Multivariate Analysis with SPSS Programme. 4th ed. Semarang: University of Diponegoro Press.

Haddad, M., Judeh, M. \& Haddad, S. (2011). Factors affecting buying behavior of an apartment and empirical investigation in Amman, Jordan. Research Journal of Applied Sciences, Engineering and Technology, 3(3), 234-239.

Bali Property Prices Recording 2013. (2013). Retrieved from http://royalgarden residence. wordpress.com/2013/01/23/harga-properti-bali-rekor-di-2013/

Katona, G. (1953). Rational behavior and economic behaviour. Psychological Review, 60(5), 307-318. 
Kishore, R. (2006). Theory of Behavioral Finance and its Application to Property Market: A Change in Paradigm: Proceedings of the Twelfth Annual Pacific Rim Real Estate Society Conference, Auckland, 22-25 January 2006. Retrieved from http://www.prres.net/ papers/ kishore_behavioural_finance_application_property_market.pdf

Knight, 0. (2014). What happened to prime residential property markets last year? Knight Frank. Retrieved from http://www.knightfrankblog.com/global-briefing/news-headlines/ whathappened-to-prime-residential-property-markets-last-year/

Koklic, M. K. \& Vida, I. (2009). A Strategik household purchase: consumer house buying behavior. Managing Global Transitions, 7(1), 75-96

Lindberg, E., Gärling, T. \& Montgomery, H. (1989). Belief-value structures as determinants of consumer behavior: A study of housing preferences and choices. Journal of Consumer Policy, 12(2), 119137.

Louviere, J. \& Timmermans, H. (1990). Stated preference and choice models applied to recreation research: A review. Leisure Sciences, 2, 112, 9-32.

Quigley, J. M. (1976). Housing demand in the short run: An analysis of polychromous choice. Explorate Economic Research, 3, 76-102.

Ratchatakulpat, T., Miller, P. \& Marchant, T. (2009). Residential real estate purchase decisions in Australia : is it more than location? International Real Estate Review, 12(3), 237-294.

Salzman, D. \& Zwinkels, R. C. J. (2013). Behavioral Real Estate (Doctoral thesis, Tinbergen Institute, 2013). Retrieved from http://papers.tinbergen.nl/13088.pdf

Si, P. T. (2012). Key factors affecting house purchase decision of customers in Vietnam. (Unpublished master thesis). University of Economics Ho Chi Minh City, Ho Chi Minh City, Vietnam.

Wang, D. \& Li, S. M. (2004). Housing preferences in a transitional housing system: the case of Beijing, China. Environment and Planning A, 36(1), 69 - 87. 